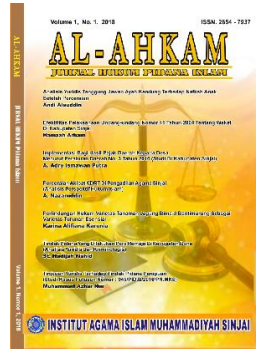

Al-Ahkam

Jurnal Hukum Pidana Islam

Volume 2, No. 1, 2020

ISSN (print) : 2654-7937

ISSN (online) : 2715-0313

Homepage : http://journal.iaimsinjai.ac.id/index.php/al-ahkam/index

\title{
FENOMENA KRIMINOLOGIS TERHADAP TINDAK PIDANA YANG TERJADI DALAM KAMPUS
}

\author{
Abunawas ${ }^{1}$ \\ ${ }^{I}$ Universitas Tanjungpura, Jl. Prof. Dr. H. Hadari Nawawi, Pontianak \\ E-mail:abu.nawas@hukum.untan.ac.id,Tlp:081331750725
}

\begin{abstract}
Abstrak
Permasalahan dunia kampus yang selama ini sering terjadi adalah tindak pidana yang tidak mencermingkan eksistensinya sebagai wadah kaum terdidik dan kaum terpelajar. Hal tersebut adalah merupakan suatu permasalahan yang harus dijawab, Sehingga mencoba untuk dijabarkan melalui dua tahapan permasalahan dalam penelitian ini, yaitu: Penyebab terjadinya tindak pidana dalam kampus dan pencegahan terjadinya tindak pidana dalam kampus. Penelitian ini merupakan kajian hukum normatif empiris dengan tehnik deskriptif kualitatif dan pendekatan penelitian yang digunakan; Pendekatan normatif, pendekatan yuridis, dan pendekatan sosiologis, . Adapun sumber data penelitian ini adalah Mahasiswa, Pejabat Kampus (Dosen), Penegak Hukum (Kepolisian, Kejaksaan dan Pengadilan) dan Pelaku Tindak Pidana, selanjutnya metode pengumpulan data yang digunakan adalah observasi, wawancara, dokumentasi dan penulusuran referensi.

Dari proses pengkajian tersebut, maka diperoleh suatu analisa bahwa: Kejadian tindak pidana dalam kampus disebabkan oleh Dua faktor. Faktor Biologis atau Pembawaan dari para pelaku dan Faktor Lingkungan yang Mempengaruhi Pelaku, Spiritualis yang kurang dimiliki oleh para pelaku. Dan adapun upaya yang dilakukan untuk mencegah terjadinya tindak pidana dalam kampus pada umumnya ada dua hal, yang pertama adalah upaya preventif Membuat peraturan atau tata tertib (kode etik), Melakukan pembinaan baik pembinaan moral dan akhlak, Pemberian ancaman. dan yang kedua adalah upaya represif meliputi : Penegakan terhadap aturan yang ada berupa skorsing atau pemecatan terhadap pelaku dan Melapor Polisi.
\end{abstract}

Kata Kunci : Kriminologi, Kejahatan dalam Kampus, Tindak Pidana.

\begin{abstract}
The problem around the campus that has often been the case is a crime that does not reflect its existence as a forum for educated and educated people. This is a problem that must be answered, so it tries to be elaborated through two stages of the problem in this study, namely: Causes of criminal acts on campus and the prevent criminal acts in the campus. This research is an empirical normative legal study with qualitative descriptive techniques and research approaches used; Normative approach, juridical approach, and sociological approach. The data sources of this research are students, campus officials (lecturers), law enforcers (police, prosecutors, and courts), and criminal offenders, then the data collection methods used are observation, interviews, documentation, and reference tracking. From the review process, an analysis was obtained that: The occurrence of criminal acts on campus was caused by two factors: such as Biological Factors or Traits of Actors, Environmental Factors Affecting Actors, Spiritual Factors which were lacking in the perpetrators. And as for the efforts made to prevent the occurrence of criminal acts on campus, in general, there are two things. The first is preventive efforts Making regulations or rules (code of ethics), Conducting both moral and moral guidance, Giving threats. And the second is repressive measures including Enforcement of existing rules like suspension or dismissal of perpetrators and Reporting the Police.
\end{abstract}

Keywords: Criminology, Crime on Campus, Crime. 


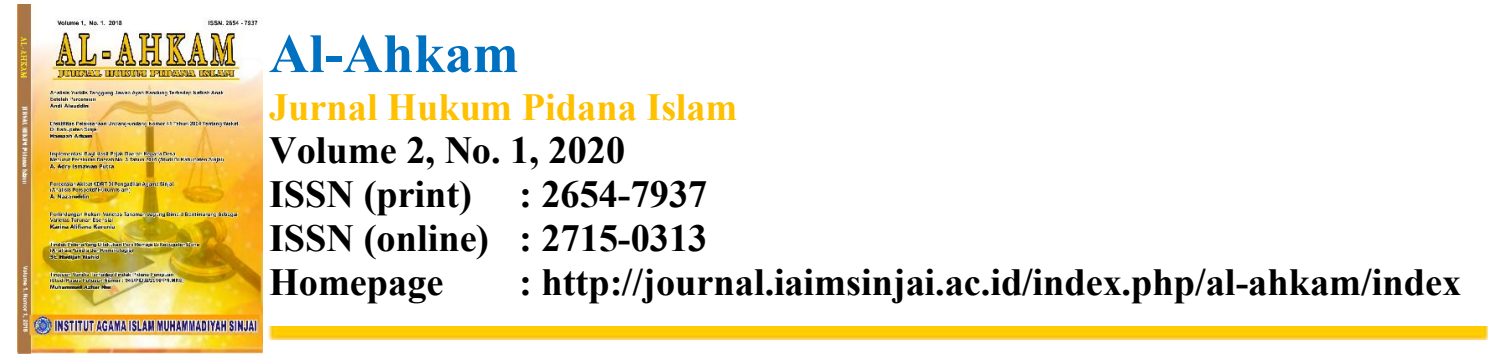

1. Pendahuluan

Kualitas dan kuantitas kejahatan semakin meningkat dengan modus operandi yang lebih bervariasi dan canggih. Perkembangan kemajuan masyarakat yang cukup pesat ini seiring dengan merebaknya fenomena supremasi hukum, hak asasi manusia, globalisasi, demokratisasi, desentralisasi, transparansi, dan akuntabilitas, telah melahirkan berbagai paradigma baru dalam melihat tujuan, tugas, fungsi, wewenang, dan tanggung jawab Kepolisian Negara Republik Indonesia yang selanjutnya menyebabkan pula tumbuhnya berbagai tuntutan dan harapan masyarakat terhadap pelaksanaan tugas Kepolisian Negara Republik Indonesia yang makin meningkat dan lebih berorientasi kepada masyarakat yang dilayaninya (Penjelasan UU No. 2/2002).

Tidak banyak dari kalangan masyarakat dan pihak akademisi memahami secara jelas tentang bentuk tindak pidana yang terjadi dalam dunia kampus khususnya kampus Universitas Islam Negeri Alauddin Makassar yang dikenal dengan istilah kampus Peradaban dan tindakan apa yang semestinya dilakukan jika terjadi perbuatan atau tindakan pidana yang terjadi dalam dunia kampus mengingat adanya statuta kampus dan karakter berfikir yang membedakan dengan situasi masyarakat pada umumnya. Mengingat hal yang demikian memunculkan banyak kalangan yang mencerca kejadian tersebut dan juga sebagian dari kalangan masyarakat menganggap bahwa hal yang demikian adalah merupakan sebuah pelanggaran atau tindakan yang dapat dipidana. Semisal yang sering ditampilkan di layar kaca maupun di media cetak lainya tentang tindakan yang dilakukan oleh oknum ataupun sebagaian dari kalangan yang sering digelar dengan kaum terpelajar, kalangan orang-orang terdidik ataupun kaum intelektual, yang sering mempertontonkan hal-hal yang tidak mencermingkan terhadap gelar yang ditelah melekat pada dirinya, seperti : Melakukan pengrusakan fasilitas kampus, melakukan tindakan kekerasan terhadap mahasiswa lainya dan tidak kalah populernya adalah melakukan demonstrasi anarkis yang mengatasnamakan rakyat akan tetapi tidak sedikit dari masyarakat yang merasakan ataupun yang menanggung dari tindakan tersebut semisal terkena lemparan batu dan juga kerusakan barang yang dimiliki.

Realitas yang harus dialami sekarang ini adalah persoalan yang menjadi tugas untuk semua, dan yang perlu kita fahami dan mencari solusi atasnya adalah apa yang menyebabkan sehingga muncul tindak pidana dalam institusi kaum terdidik, kaum yang memahami baik atau buruknya suatu tindakan, benar atau salahnya suatu perbuatan, dan memahami akan akibat yang dimunculkan oleh tingkah laku tersebut. Sebagai suatu bentuk partisipasi dalam menjawab pertanyaan tersebut dapat di fahami dalam perspektif kriminologi sebagai salah satu cabang ilmu yang membahas tentang kejahatan dan pelaku kejahatan sebagai sebuah gejala sosial, Edwin H. Sutherland . Kriminologi adalah keseluruhan ilmu pengetahuan mengenai kejahatan sebagai gejala sosial. (Ediwarman, 1999: 15)

Pandangan kriminologi sangatlah penting dikaji dalam menilai dan mengukur serta memahami terhadap apa yang dilakukan oleh kalangan intelektual tersebut dan atas perlakuan terhadap mereka yang diduga melakukan tindakan Kriminal atau tindak pidana, yang mendapat ganjaran atau hukuman atas perbuatan yang telah dilakukan oleh pihak yang berwenang. Mulai dari pihak kampus yang memberikan hukuman kepada pelaku seperti : hukuman biasa, skorsing, denda dan Tidak banyak dari mereka di keluarkan secara terhormat ataupun tidak terhormat, serta hukuman yang brasal dari pihak yang berwenang dari luar kampus yang tidak lain adalah aparat penegak hukum ( POLISI ) adalah kurungan penjara dan tidak sedikit dari mereka mendapatkan sanksi tambahan 


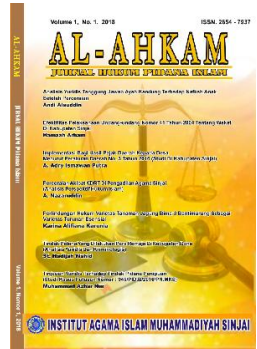

yaitu sanksi sosial dari kalangan civitas akademika maupun sanksi masyarakat pada umumnya.

Keadaan inilah yang mendorong, memotifasi, dan memunculkan niat penulis untuk membahas, menganalisa, mengkaji dan mengungkap permasalahan tersebut. Berdasar dari paparan latar belakang diatas penulis maka penulis melakukan penelitian yang berjudul : Fenomena Kriminologis Yang Terjadi Dalam Kampus Peradaban. Untuk lebih memahami secara mendalam tentang bagaimana bentuk-bentuk tindak pidana yang terjadi dalam kampus, bagaimana latar belakang atau faktor faktor terjadinya tindak pidana yang terjadi dalam kampus, upaya-upaya yang dilakukan dalam mencegah terjadikan tindak pidana dalam kampus serta bagaimana pandangan masyarakat tentang tindakan yang dilakukan tersebut, meskipun sebenarnya penelitian ini telah lama dilakukan akan tetapi karena mengingat belum adanya penulis yang memaparkan dengan jelas tentang fenomena kriminologis yang terjadi dalam kampus maka penulis berinisiatif untuk menuangkan dalam jurnal ini dalam perspektif kekinian.

Berdasarkan latar belakang di atas maka untuk menjelaskan secara terarah dengan mendalami sesuai dengan tujuannya, maka dapat dirumuskan permasalahanya sebagai berikut : Bagaimanakah bentuk-bentuk tindak pidana yang terjadi dalam kampus, Faktorfaktor apakah yang mempengaruhi terjadinya tindak pidana dalam kampus, dan Upaya-upaya Apakah yang dilakukan dalam mencegah terjadikan tindak pidana dalam kampus. Hal ini didasarkan pada objek kajian kriminologi berdasarkan aliran hukum atau yuridis (Topo santoso, 2009: 13).

\section{Metode}

Metode penelitian yang digunakan adalah penelitian normatif empiris. Penelitian hukum normatif empiris adalah penelitian hukum mengenai pemberlakuan ketentuan hukum normatif (kodifikasi, undang-undang atau kontrak) secara in action pada setiap peristiwa hukum tertentu yang terjadi dalam masyarakat (Abdulkadir Muhammad, 2004: 134). Penelitian ini dilakukan di lingkungan sivitas akademika UIN Alauddin Makassar.

Adapun Pengambilan data dilakukan dengan Studi dokumen atau bahan pustaka; langkah awal dari setiap penelitian hukum karena hukum selalu bertolak kepada premis normatif dan hukum merupakan ilmu terapa (Aminuddin, 2004: 8), dan melakukan Pengamatan terhadap sivitas akademika untuk memilih responden dalam penelitian adapun responden pada penelitian ini melibatkan pejabat, Dosen, dan mahasiswa. Peneliti menafsirkan fakta-fakta yang didapat dalam penelitian, dan akan menjadi konsep terhadap gejala yang di amati. Wawancara, yaitu teknik pengumpulan data yang dilakukan untuk mendapatkan informasi dengan cara bertanya langsung kepada narasumber yang dianggap memiliki kewenangan terhadap segala bentuk permasalahan yang terjadi dalam kampus khsusnya mengenai hal-hal yang akan diteliti dan ditambah wawancara langsung dengan pelaku tindak pidana. Kemudian Peneliti mengajukan pertanyaanpertanyaan yang disiapkan kepada mahasiswa dan dosen untuk memperoleh jawabanjawaban yang relevan dengan masalah penelitian kepada responden yang berjumlah 100 responden yang terdiri dari 25 orang Dosen dan 75 orang Mahasiswa, melakukan Angket yaitu dilakukan dengan tehnik mendatangi responden kemudian dilakukan Tanya jawab mendalam bardasarkan naskah pertanyaan yang telah disiapkan sebelumnya, bentuk pertanyaan di format dalam dua kategori yaitu format terbuka (open form) dan format tertutup (close Form).

Data yang diperoleh kemudian dianalisis secara kualitatif. Analisis kualitatif dilakukan dengan mendeskripsikan serta menggambarkan data dan fakta yang dihasilkan 


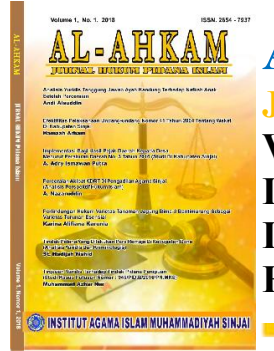

Al-Ahkam

Jurnal Hukum Pidana Islam

Volume 2, No. 1, 2020

ISSN (print) : 2654-7937

ISSN (online) : 2715-0313

Homepage : http://journal.iaimsinjai.ac.id/index.php/al-ahkam/index

dari suatu penelitian di lapangan dengan suatu interpretasi, evaluasi, dan pengetahuan umum.

\section{Pembahasan}

\section{a. Fenomena Yang Menyebabkan Terjadinya Tindak Pidana Dalam Kampus}

Kejahatan lebih dekat dari urat leher manusia. Ketika manusia menafikkanya dan mengatakan diri steril dari kosa kata itu, berarti telah mengingkari keberadan sebagai individu yang berintraksi dengan mahluk sosial, karena dimana ada manusia disana ada kejahatan (Yesmil Anwar, 2009: Vii). Sebuah pernyataan yang tendensius dan seolaholah menuduh, karena sebenarnya dalam peristiwa kejahatan, peran manusia sebagai pelaku, bisa sebagai korban, dan bisa pula sebagai kedua-duanya sekaligus. Bahkan peran manusia bisa mulai sebagai penonton langsung ketika kejahatan tengah terjadi, atau sebagai penonton tidak langsung melalui berita-berita di Koran, majalah, atau televisi, yang setiap hari mempertontonkan kejahatan "siap saji" secara amat gamblang. Ketika ingin bereaksi membantah bahwa tak berurusan dengan kejahatan dalam bentuk apapun, baik sebagai korban maupun sebagai pelaku, atau keduanya, bahkan sebagai penonton sekalipun, maka pada saat yang bersamaan sebenarnya telah berperan sebagai bagian dari dinamika kejahatan itu sendiri, yaitu pengingkaran. Itulah reaksi yang wajar dari manusia yang secara spontan, biasanya terlontar begitu saja untuk menolak, ketika dilibatkan pada suatu yang dianggap oleh hukum, masyarakat, budaya dan atau agama sekalipun. Hal itu sangat manusiawi. Berangkat dari pandangan tersebut, sangatlah wajar jika terjadi tindak pidana dalam kampus yang terdapat manusia yang menuntut ilmu, terlepas dari eksistensinya sebagai mahasiswa dalam kampus tenyata jiwa kemanusiaanya tidak terlepas, sehingga di dalam kampus terjadi tindak pidana.

Dalam memaparkan tentang faktor terjadinya tindak pidana dalam kampus, yang nyatanya adalah tempat para orang terpelajar tempat manusia yang bermoral, manuasia yang faham akan baik dan buruknya suatu tindakan baik dari sisi ilmu dunia maupun ilmu akhirat. Hal yang demikian lebih diperparah jika kampus tersebut berasaskan nilai Agama seperti kampus yang bernuansa Islam Seperti UIN dan IAIN. Jika sepintas nama tersebut Menebarkan aurah Religius dan moralitas, karena dalam pelaksanaan system pelaksanaan pendidikanya memasukkan nilai-nilai keagamaan dan moralitas, hal yang demikian terealisasi dalam pembuatan system pembelajaran dan tambahan mata kuliah khusus yang mengarahkan kepada nilai dan ajaran agama. Akan tetapi hal yang demikian tidak menghindarkan dari para civitas akademika yang ada didalamnya terlepas dari perbuatan yang melanggar peraturan semisal tindak pidana. Yang demikian sesuai dengan hasil penelitian yang dilakukan terjadinya tindak pidana dalam kampus sebagai mana di paparkan dalam paparan sebelumnya.

Untuk memahami latar belakang atau faktor kriminolgis terjadinya tindak pidana secara umum dapat difahami faktor kejahatan merupakan perbuatan tidak normal (tidak selaras dengan norma) atau abnormal, yang jika dilihat dari sudut sipelaku, maka penampilan perilakunya yang abnormal tersebut dapat terjadi karena beberapa kemungkinan (Soedjono, 1977: 19): Pertama faktor yang bersifat psikopatologis, yaitu yang dilakukan oleh orang-orang: yang menderita sakit jiwa dan yang tidak sampai sakit jiwa, tetapi terdapat kelainan karena kondisi IQ -nya dan sebagainya. Kedua faktor kegiatan jiwa yang wajar, namun terdorong menyetujui melanggar undang-undang yang dilakukan oleh orang- orang dengan perbuatan melanggar hukum secara professional. Dan faktor sosial yang langsung mempengaruhi individu atau kelompok sehingga yang bersangkutan mengalami kesulitan kejiwaan, yaitu yang dilakukan oleh orang-orang tidak mampu menyesuaikan diri dengan kondisi sosial yang dihadapinya. Jadi secara 


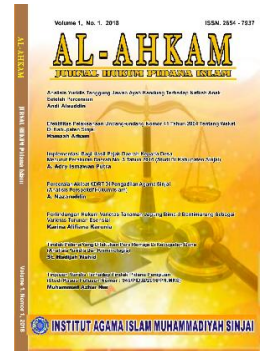

Volume 2, No. 1, 2020

ISSN (print) : 2654-7937

ISSN (online) : 2715-0313

Homepage : http://journal.iaimsinjai.ac.id/index.php/al-ahkam/index

psikologi kejahatan adalah perbuatan manusia yang abnormal yang bersifat melanggar norma hukum yang disebabkan oleh faktor-faktor kejiwaan si pelaku kejahatan tersebut.

Untuk membandingkan dan memahami faktor terjadinya kriminalitas dalam kampus, hal yang demikian dipaparkan oleh hasil penelitian 100 responden yang terdiri dari 75 mahasiswa dan 25 dosen dihasilkan data sebagai berikut :

FAKTOR TERJADINYA TINDAK PIDANA YANG TERJADI DALAM KAMPUS UIN ALAUDDIN MAKASSAR

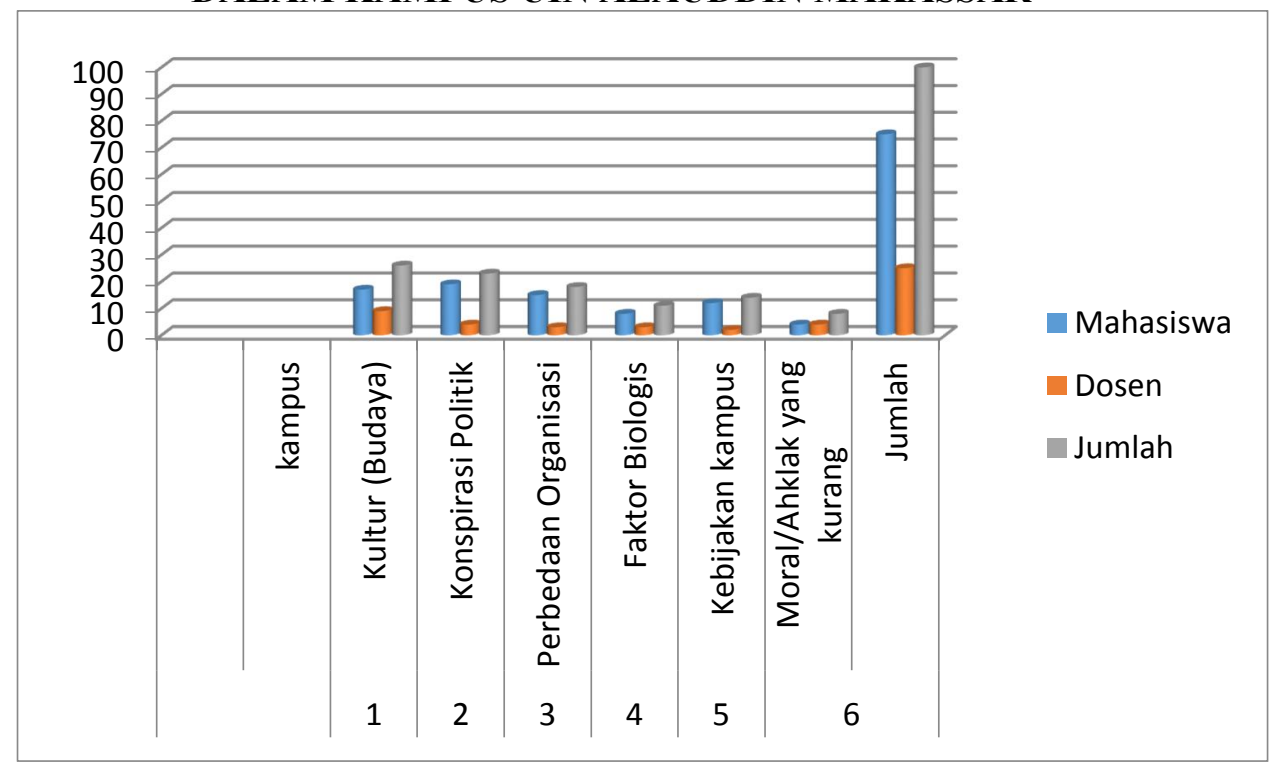

Sumber data : Data Primer yang telah diolah tanggal 2 Februari 2011

Berdasarkan tabel diatas menunjukkan bahwa Faktor tejadinya tindak pidana dalam kampus adalah dikarenakan faktor budaya yang dimiliki oleh para pelaku dinyatakan oleh 26 orang atau kisaran $26 \%$ dari 100 jumlah responden yang brasal dari 25 dosen dan 75 mahasiswa, faktor konspirasi politik menunjukkan bahwa dari jumlah responden menyatakan hal tersebut sebanyak 23 orang atau kisaran $23 \%$, Faktor perbedaan organisasi berdasarkan data responden 18 orang menyatakan hal tersebut atau kisaran 18 $\%$, Faktor biologis Sebanyak 11 orang atau kisaran 11\%, Kebijakan Kampus 14 Orang atau kisaran $14 \%$ dan yang terakhir faktor yang menyebabkan terjadinya tindak pidana dalam kampus karena kurangnya moralitas yang dimiliki civitas akademika adalah 8 $\%$ Atau jumlah responden yang menyatakan hal tersebut sebanyak 8 orang.

Jika berbicara tentang faktor terjadinya tindak pidana dalam kampus menurut dekan fakultas tarbiyyah yang pernah menjabat sebagai Pembantu Rektor III UIN Alauddin Makassar Mengatakan Bahwa faktor terjadinya tindak pidana dalam kampus Adalah (Salehuddin yasin, 2011) : Pertama Faktor bawaan atau karakter tertentu. Pandangan tersebut dilatari atas beberapa mahsiswa yang memang dulunya ketika sebelum masuk di perguruan tinggi memang sudah dikenal dengan karakter atau pembawaanya tersebut sehinnga dalam melakoni kehidupan dalam kampus pembawaanya ikut mempengaruhi kepribadianya ,sehingga mereka melakukan hal yang sama dilakukan sebelum masuk dalam kampus misalkan kebiasaan meminum minuman keras, berkelahi, dll; Kedua Faktor Kultur dari perbedaaan organisasi kedaerahan. Hal yang menjadi lumrah dewasa kini ketika terjadi perkelahian ataupun tindakan yang lain yang mengarah kepada tindakan pidana dalam kampus tidak akan terlepas dari pengaruh maupun keikut 


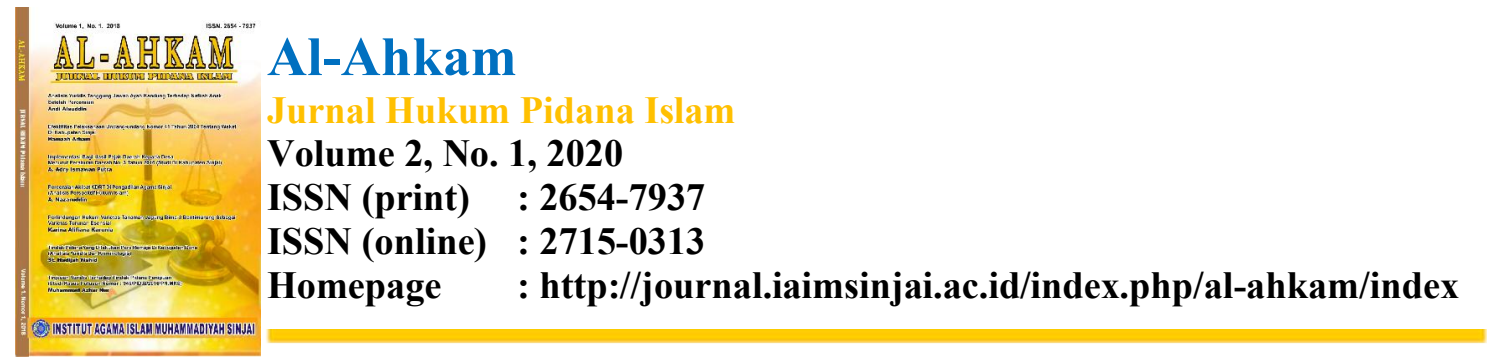

sertaan dari oraganisasi kedaerahan, baik disengaja maupun tidak itu akan menjadi hal yang mudah mempengaruhi tindak pidana dalam kampus, karena bagaimana tidak ketika suatu kejadian misalkan menyebutkan asal pelaku dari daerah tertentu maka orang yang sedaerah denganya akan dengan mudah terpropokasi untuk melakukan tindakan perlawanan maupun pembelaan ataupun sebaliknya. Ketiga Faktor Kesalah fahaman. Kesalafahaman adalah merupakan faktor umum yang mendorong maupun mempengaruhi terjadinya tindak pidana dalam kampus, sebut saja misalkan kejadian 1 september pada dasarnya, kejadian tersebut brawal dari kebijakan kampus dalam pelaksanaan orentasi pengenalan Kampus (OPAK) yang kegiatanya diselenggarakan selama 4 hari. Dalam 4 hari ini di bagi menjadi 2 bagian, dua hari menjadi wewenang dari BEM Universitas dan Dua harinya lagi wewenang BEM Fakultas, akan tetapi karena kebiasaan yang sering terjadi Pelaksanaan OPAK dilaksanakan Oleh Masing-masing Fakultas, sehingga memunculkan masalah padahal hal yang demikian tujuanya baik agar semua ikut terjun pada kegiatan Orientasi Pengenalan Kampus tersebut, tetapi kebanyakan dari mahasiswa kurang memahami secara menyeluruh sehingga mereka dengan mudah melakukan tindakan yang dapat menceder ai dirinya sendiri hingga merusak dirinya sendiri. Keempat Karena faktor security belum bekerja secara optimal.

Menurut Ambo Asse. Menyatakan Bahwa pada dasarnya yang menyebabkan terjadinya tindak pidana dalam kampus karena : Pertama, Ketidak Puasan Mahasiswa terhadap kebijakan yang dikeluarkan oleh pimpinan kampus. Ketidak puasan mahasiswa terhadap kebijakan yang dikeluarkan oleh pihak kampus pada dasarnya menyebabkan terjadinya tindak pidana dalam kampus. Hal yang demikian adalah salah satu dari sikap mahasiswa dalam menanggapi kebijakan yang tidak sesuai dengan pendapat ataupun pikiran mahasiswa. Kedua, ketidak sadaran diri sebagai Mahasiswa maupun Dosen. Eksistensi mahasiswa bukan hanya dililihat dari sisi jasmaniah akan tetapi eksistensi yang sebenarnya Adalah eksistensi rohaniah yang melambangkan fungsinya sebagai mahasiwa yang intelektual yang menjunjung tinggi moralitas dan nilainilai hidup dalam masyarakat, termasuk menjunjung tinggi nilai-nilai keislaman dan senantiasa memberikan ajakan kebaikan itulah mahasiswa yang sebenarnya yang sadar akan eksistensinya.

Kasus 1 september adalah merupakan suatu pristiwa sejarah tersendiri bagi Universitas Islam Negeri (UIN) Alauddin Makassar, karena kasus tersebut adalah merupakan suatu pristiwa yang sebenarnya tidak layak terjadi di dalam kampus, tapi terlepas dari hal tersebut yang menjadi objek utama yang harus difahami bersama adalah kenapa hal yang demikian bisa terjadi. Untuk menjawab hal tersebut di paparkan dalam hasil wawancara dengan para mahasiswa yang terlibat dan hadir pada saat itu diantaranya: Awaluddin adalah mahasiwa fakultas syariah dan hukum yang juga merupakan Ketua (Badan Eksekutif Mahasiswa) BEM F-Syariah dan Hukum pada saat itu, Mengatakan bahwa faktor terjadinya pristiwa 1 september 2010 yang barasal dari Aksi damai yang dilakukan oleh BEM- Fakultas se UIN dan kawan-kawan, yang memunculkan kerusakan pada bagian tertentu dalam kampus adalah disebabkan: Adanya provokasi yang dilakukan oleh oknum tertentu agar terjadi hal-hal yang tidak diinginkan; Adanya ketersingungan dari oknum tertentu dari tindakan satpam.; Adanya kesalah fahaman dan Adanya kejengkelan terhadap birokrasi yang tidak mendengarkan aspirasi mahasiswa. Sementara Hermawan yang merupakan mahasiswa yang pernah menerima Ilmu di Fakultas Syariah dan Hukum mengatakan bahwa faktor terjadinya kericuhan ataupun pengrusakan yang terjadi di kampus 1 dan Kampus II adalah karenaterjadinya pemukulan terhadap mahasiswa oleh pihak satpam sehingga 


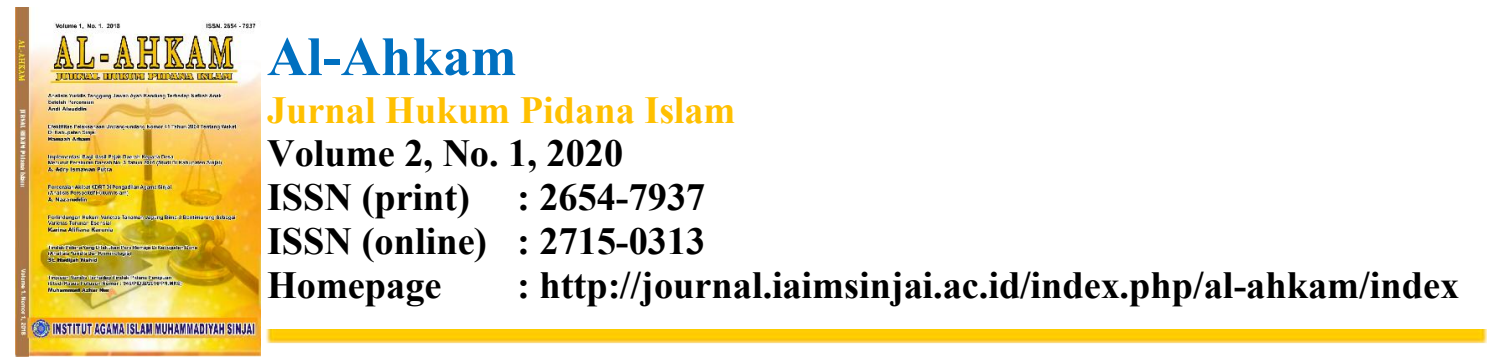

banyaknya mahasiswa yang dibawa kerumah sakit, dan menyebabkan terjadinya kekacauan dan pengrusakan.

Dari wawancara dapat di ambil sebuah kesimpulan bahwa peristiwa tersebut berawal dari kegiatan OPAK (Orientasi Pengenalan Akademik Dan Kampus) yang di dalamnya terjadi pungutan liar (Pungli) dan adanya persaingan antara BEM- U dan BEMF Se UIN Alauddin Makassar. Awal mula dari terjadinya tindakan anarkis dan pengerusakan barang di karenakan adanya provokasi dan tindakan anarkis karena adanya pemukulan terhadap mahasiswa dan Juga surat edaran yang seakan- akan menghakimi langsung komunitas tertentu yang tidak adil.

Lain halnya dengan paparan dari pihak kepolisian yang menyatakan bahwa faktor terjadinya tindak pidana dalam kampus dikarenakan adanya kebiasaan muncul dalam kehidupan kampus, kebiasaan untuk melakukan tindakan anarkis dan juga kebiasaan memancing terjadinya pencurian hingga penganiayaan yang mengakibatkan terjadinya pembunuhan dalam kampus, hal tersebut disebabkan karena banyaknya komunitas kelompok dan tidak adanya kualitas standar pengamanan dalam kampus terutama yang berkaitan dengan keamanan, lahan parkirdan pengamanan lahan parkir.

Berdasarkan uraian di atas dan juga landasan teori yang telah dipaparkan dapat di klasifikasi berdasarkan hasil penelitian bahwa faktor penyebab terjadinya tindak pidana dalam kampus adalah Pertama Faktor Umum yang Meliputi : Faktor Biologis atau Pembawaan dari para pelaku; Faktor Lingkungan yang Mempengaruhi Pelaku; Faktor Spiritualis yang kurang dimiliki oleh para pelaku. Kedua Faktor Internal dalam Kampus Meliputi : Lemahnya pihak keamanan dalam mengontrol segala aktivitas dalam kampus, Serta kurangnya kegiatan yang menyatukan para mahasiswa sehinga jalinan komunikasi diatara mereka tidak berjalan dengan baik; Pembinaan yang kurang kepada mahasiswa baik itu pembinaan mental maupun pembinaan moral; Adanya persaingan antar kelompok baik kelompok etnis dalam hal ini organda maupun kelompok organisasi lainya pada tiap suksesi dalam kampus; Adanya konspirasi dan Provokasi oleh oknum tertentu; Tidak adanya kedekatan antara pimpinan, bawahan dan mahasiswa, sehinnga kadang memunculkan mis komunikasi; Ketidak Puasan Mahasiswa terhadap kebijakan yang dikeluarkan oleh pimpinan kampus; dan Ketidak sadaran diri sebagai Mahasiswa, Dosen dan Pimpinan.

\section{b. Upaya - Upaya Untuk Mencegah Fenomena Terjadinya Tindak Pidana Dalam Kampus}

Kebijakan atau upaya penanggulangan kejahatan pada hakikatnya merupakan bagian integral dari upaya perlindungan masyarakat (social defence) dan upaya mencapai kesejahteraan (social welfare). Kebijakan penanggulangan kejahatan atau bisa disebut juga politik kriminal memiliki tujuan akhir atau tujuan utama yaitu "perlindungan masyarakat untuk mencapai kesejahteraan masyarakat". Kebijakan penanggulangan kejahatan (criminal policy) itu sendiri merupakan bagian dari kebijakan penegakan hukum (law enforcement policy). Kebijakan penegakan hukum merupakan bagian dari kebijakan sosial (scsial policy) dan termasuk juga dalam kebijakan legislatif (legislative policy). Politik kriminal pada hakikatnya juga merupakan bagian integral dari kebijakan sosial yaitu kebijakan atau upaya untuk mencapai kesejahteraan sosial (Nawawi Arief, 2008: 2)

Terjadinya tindak pidana dalam Kampus adalah merupakan suatu hal yang sangat lumrah sebagai manusia biasa, akan tetapi jika tidak dilakukan upaya pencegahan maka tindakan tersebut akan menjadi bencana bagi manusia begitupun halnya dengan pihak kampus jika tidak melakukan tindakan terhadap pelaku tindak pidana dalam kampus maka akan terjadi hal yang sangat menjerumuskan bagi para civitas akademika, Upaya atau kebijakan umum dalam masyarakat untuk melakukan pencegahan dan 


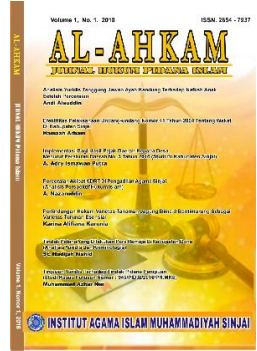

penanggulangan kejahatan termasuk bidang "kebijakan Kriminal" (Criminal policy) kebijakan criminal ini pun tidak terlepas dari kebijakan yang lebih luas, yaitu : "kebijakan sosial" (Social Policy) yang terdiri dari kebijakan atau Upaya-upaya untuk kesejahteraan sosial (social welfare policy) dan upaya-upaya untuk perlindungan Masyarakat (social defence policy) (Nawawi Arief, 2008: 77).

Menurut G.P. Hoefnagels yang dikutip oleh Barda Nawawi Arief, bahwa upaya penangulangan kejahatan dapat ditempuh dengan Penerapan hukum pidana (criminal law application); Pencegahan tanpa pidana (prevention without punishment); Mempengaruhi pandangan masyarakat mengenai kejahatan dan pemidanaan lewat media massa (influencing views of society on crime and punishment/mass media) (Nawawi Arief, 2011: 45). Berdasarkan pendapat tersebut maka upaya penanggulangan kejahatan secara garis besar dapat dibagi menjadi dua, yakni jalur penal dan non penal. Penanggulangan Kejahatan Dengan Hukum Pidana (Upaya Penal), (Nawawi Arief, 2011: 45) bahwa upaya penanggulangan lewat jalur penal ini bisa juga disebut sebagai upaya yang dilakukan melalui jalur hukum pidana. Upaya ini merupakan upaya penanggulangan yang lebih menitikberatkan pada sifat represif, yakni tindakan yang dilakukan sesudah kejahatan terjadi dengan penegakan hukum dan penjatuhan hukuman terhadap kejahatan yang telah dilakukan. Selain itu, melalui upaya penal ini, tindakan yang dilakukan dalam rangka menanggulangi kejahatan sampai pada tindakan pembinaan maupun rehabilitasi.

Penanggulangan Kejahatan Tanpa Hukum Pidana (Upaya Non Penal) (Nawawi Arief, 2011: 45) bahwa upaya penanggulangan lewat jalur non penal ini bisa juga disebut sebagai upaya yang dilakukan melalui jalur di luar hukum pidana. Upaya ini merupakan upaya penanggulangan yang lebih menitikberatkan pada sifat preventif, yakni tindakan yang berupa pencegahan sebelum terjadinya kejahatan. Melalui upaya non penal ini sasaran utamanya adalah menangani faktor-faktor kondusif penyebab terjadinya kejahatan, yakni meliputi masalah-masalah atau kondisi-kondisi sosial yang secara langsung atau tidak langsung dapat menimbulkan atau menumbuh suburkan kejahatan.

Dengan demikian, sekiranya kebijakan penanggulangan kejahatan (politik kriminal) dilakukan dengan menggunakan sarana Penal dan Non Penal. Akan tetapi permasalahan tersebut secara eksplisit berbeda dengan dunia kampus. oleh karenanya dalam melihat upaya yang dilakukan oleh pihak kampus dipaparkan oleh 100 responden dari 75 mahasiswa dan 25 dosen menyatakan bahwa :

\section{TINDAKAN PENCEGAHAN YANG DILAKUKAN UNTUK MENCEGAH TERJADINYA TINDAK PIDANA DALAM KAMPUS UIN ALAUDDIN MAKASSAR}




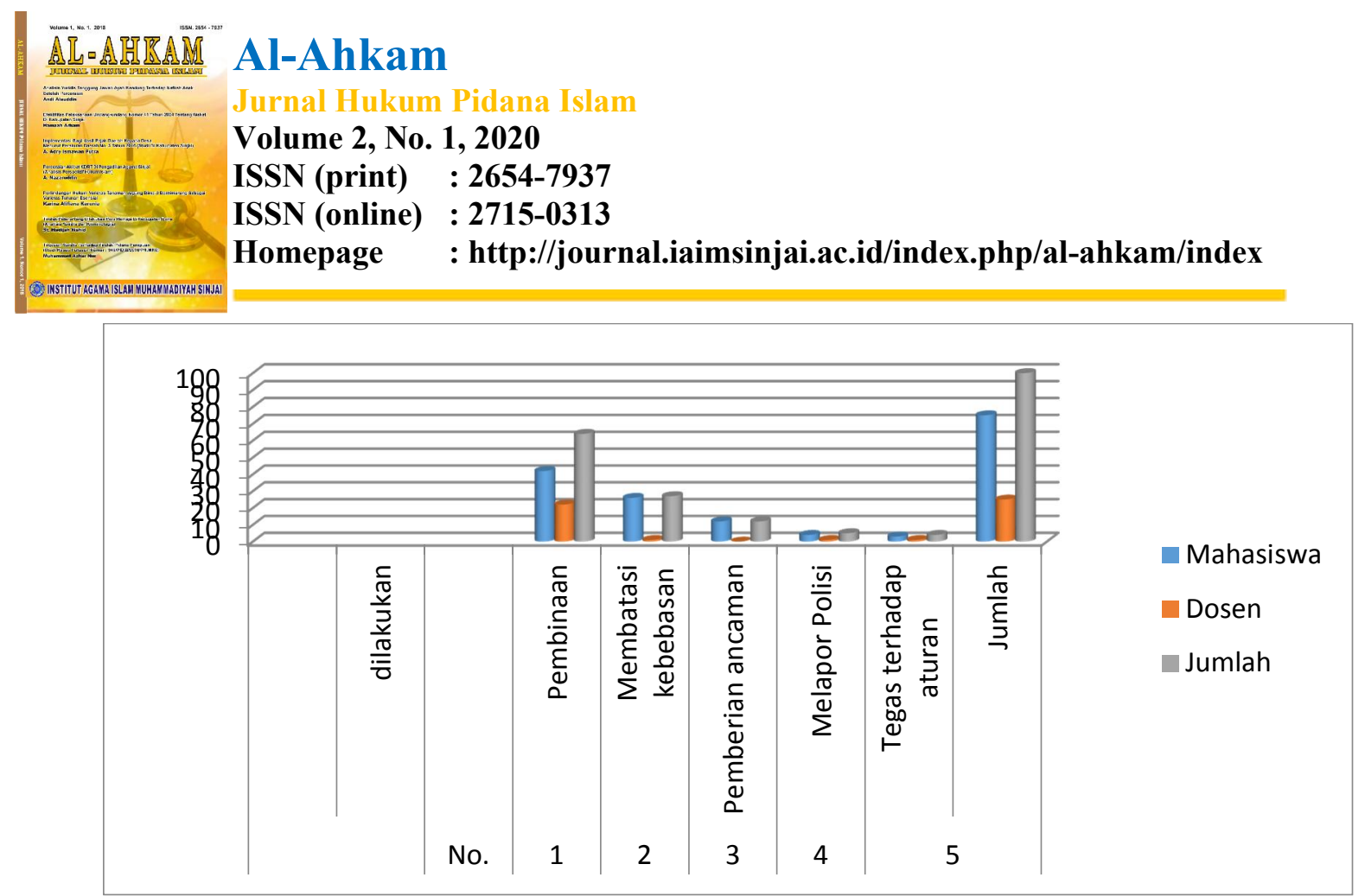

Sumber data : data primer yang telah diolah tanggal 3 Maret 2011

Data tersebut diatas menunjukan bahwa tindakan yang dilakukan untuk mencegah terjadinya tindak pidana dalam kampus berdasarkan angket dari 25 dosen dan 75 mahasiswa menunjukkan bahwa hal yang paling menonjol dilakukan adalah melakukan Pembinaan terhadap pelaku hal tersebut tercermin dalam jumlah responden yang memilih sebanyak 64 orang atau kisaran $64 \%$ dari akumulasi 100 peserta responden, tindakan selanjutnya yang sering dilakukan adalah membatasi pandangan politik atau pandangan tertentu (tidak transparan) jumlah responden yang memilih hal tersebut sebanyak 15 orang atau sekitar $15 \%$, membatasi kebebasan salah satu hal yang dirasakan oleh mahasiswa ubtuk mencegah terjadinya tindak pidana dalam kampus hal ini tercermin dalam data responden yang dimiliki oleh Mahasiswa yang memilih hal tersebut sebanyak 12 orang atau kisaran $12 \%$, sedangkan yang memilih opsi Melapor polisi dan tegas terhadap aturan sebanyak 9 orang atau $9 \%$.

Sedangkan menurut paparan pimpinan kampus, upaya yang dilakukan untuk mencegah terjadinya tindak pidana dalam kampus adalah Membuat kebijakan bersama dalam fakultas yaitu menerapkan system "tree ways Communication" system ini mencoba untuk melakukan pendekatan terhadap para pihak yang berperan penting dalam proses pembinaan dan pendidikan terhadap mahasiswa. Komunikasi yang dimaksud adalah komunikasi yang intens dilakukan dalam menghadapi berbagai masalah yang terjadi yang berkaitan dengan kebijakan maupun permasalahan yang terjadi dikalangan mahasiswa, dibicarakan bersama oleh mahasiswa, pimpinan dan juga meminta pertimbangan para orang tua yang terkait. Hal yang demikian diharapkan dapat memajukan reading orientik (kajian orentasi) para mahasiswa demi tercapainya apa yang diingingkanya dalam proses perkuliahan dalam kampus. Disamping hal yang demikian salah satu yang dilakukan dalam mencegah terjadinya mis komunikasi atau tidak jalanya komunikasi diantara civitas akademika diadakan pembimbingan terhadap para mahasiswa maupun dosen dalam menunjang eksistensinya ditengah pergolakan kampus terutama mahasiswa maupun dosen yang memegang amanah sebagai penyambung aspirasi dari orang yang diwakilinya, seperti para pengurus BEM, Para Pengurus HMJ sejajaran dan juga pimpinan kampus.

Dalam melihat fenomena kejadian yang terjadi terutama kejadian yang dilakukan oleh para mahasiswa yang melanggar aturan dalam hal ini aturan umum sebagai bangsa dan bernegara maupun pelanggaran kode etik langkah yang dilakukan untuk menindak dan memberikan solusi, sebagai pimpinan yang sering dilakukan adalah memberikan 


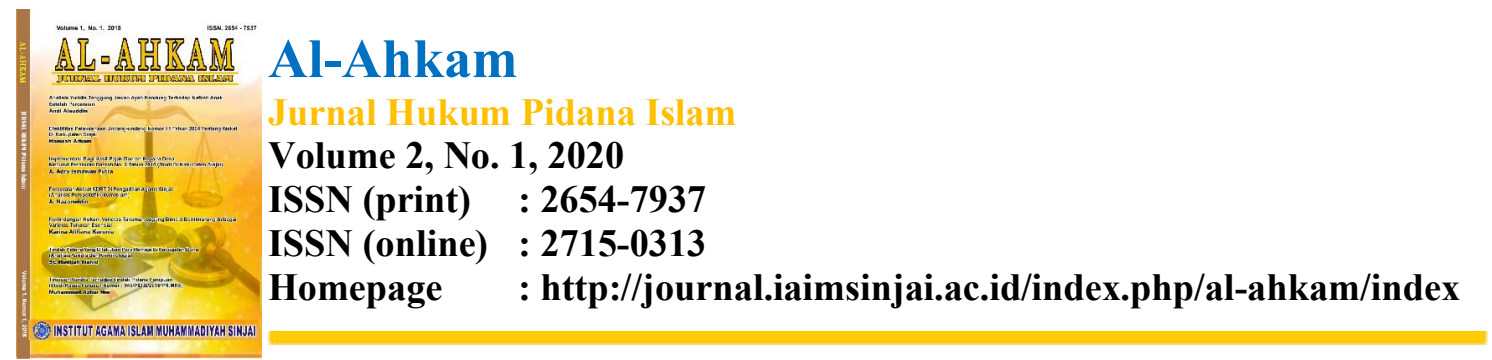

tindakan sesuai dengan besar tidaknya pelanggaran yang dilakukan, ketika pelanggaran yang dilakukan masih berada pada tataran yang normal dan masih bisa ditolerir maka pihak pimpinan dalam artian pimpinan fakultas memberikan teguran yang sewajarnya, untuk mencegah terjadinya hal yang lebih besar, akan tetapi jika masih melakukan akan dilakukan tindakan yang professional dan proporsional. Jika pelanggaran yang dlakukan melanggar kode etik akan disampaikan ke pimpinan, akan tetapi jika mengarah kepada tindakan yang melanggar aturan umum yang berat akan diserahkan kepada pihak yang berwenang dalam hal ini pihak berwajib ( kepolisian) (Wahyuddin Naro, 2011).

Tindak tindak pidana dalam kampus pada saat ini adalah dengan melakukan berbagai pembinaan dan pelatihan yang diharapkan nantinya mahasiswa dapat memiliki akhlak karimah dan moralitas yang tinggi, akan tetapi hal yang demikian belum maksimal karena adanya permasalahan dalam pelaksanaanya. kemudian dengan melakukan perbaikan sumber daya manusia yang lebih baik, dan melakukan perbaikan terhadap kesejahteran dan juga sifat proporsional yang dimiliki oleh civitas akademika (Abustani Ilyas, 2011). Penegakan aturan yang ada, dan menindak semua pelaku yang melanggar atuaran; Rutin melakukan pemeriksaan; Patroli diperketat; Melakukan pembimbingan; Memberikan peringatan terhadap pelaku sesuai dengan pelanggaranya.

Hal yang menjadi patokan yang perlu difahami adalah menindak semua pelaku pelanggaran dengan melihat pelanggaran yang dilanggarnya dan begitu juga konsekuensi yang diberikan adalah bagaimana konsekuensi tersebut dapat memberikan efek jera dan kesadaran dalam diri pelaku karena itu adalah bahagian dari pendidikan yang harus dijujung tinggi sebagai wadah dan media pendidik yang baik.

Lebih lanjut dipaparkan oleh pimpinan fakultas dakwah dan komunikasi Untuk menghindari terjadinya tindak pidana dalam kampus, pimpinan dalam hal ini dekan melakukan beberapa cara di antaranya adalah melakukan silaturrahim dengan semua unsur pimpinan, bawahan dan mahasiswa atau mengadakan halal bi halal untuk memperbaiki tali silatturrahim (Abustani Ilyas, 2011). Melakukan sosialisasi peraturan kode etik dalam kampus, dan yang terakhir jika terjadi tindak pidana akan diserahkan kepada pihak yang berwenang. Hal yang demikian adalah salah satu cara yang cukup efektif dilakukan. Adapun tindakan yang dilakukan untuk mencegah terjadinya tindak pidana dalam kampus : Membuat aturan Atau membuat tata tertib, Membuat dan melindungi barang inventaris kampus, Memberi Ancaman Kepada para pelaku (Ambo Asse, 2011).

Hal yang demikian adalah merupakan suatu langkah yang dilakukan untuk mencegah dan menindaklanjuti tindak pidana yang terjadi dalam kampus. Kesemuanya itu terealisasi dengan baik dan efektif. Berdasarkan uraian di atas dapat di klasifikasi berdasarkan hasil penelitian bahwa Upaya yang dilakukan dalam mencegah terjadinya tindak pidana dalam Kampus sebagai berikut: Pertama Upaya Preventif : Membuat praturan atau tata tertib (kode etik), Pemberian Kegiataan yang padat, terutama yang berkenaan dengan mata kuliah; Melakukan pembinaan baik pembinaan moral dan akhlak; Melakukan kegiatan silaturrahim atau halal bi halal dengan segenap civitas akademika; Pemberian ancaman. Kedua Upaya Represif; Memberikan skorsing atau pemecatan terhadap pelaku, dan menindak para pelaku dengan peroporsional dan provesional; Melapor Polisi; Penegakan terhadap aturan yang ada.

\section{Simpulan}

Dunia pendidikan dalam kampus adalah merupakan dunia akademis tempat berkumpulnya kaum intelektual yang diharapkan banyak memberikan kontribusi dalam 


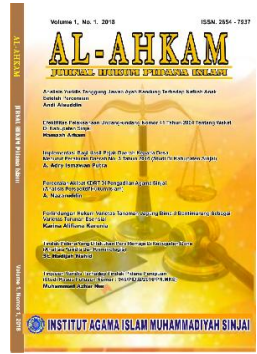

Volume 2, No. 1, 2020

ISSN (print) : 2654-7937

ISSN (online) : 2715-0313

Homepage : http://journal.iaimsinjai.ac.id/index.php/al-ahkam/index

perkembangan peradaban manusia. Pada prakteknya telah terjadi banyak tindak pidana yang disebabkan oleh Faktor Umum dan faktor Internal dalam kampus seperti : Faktor Biologis atau Pembawaan dari para pelaku, Faktor Lingkungan yang Mempengaruhi Pelaku, Faktor Spiritualis yang kurang dimiliki oleh para pelaku, olehnya itu perlu dilakukan upaya untuk mencegah perbuatan tersebut. Sebagai tempat kaum terdidik pihak kampus telah melakukan banyak usaha untuk mencegah terjadinya tindak pidana dalam kampus pada umumnya ada dua hal, yang pertama adalah upaya preventif Membuat praturan atau tata tertib (kode etik), Melakukan pembinaan baik pembinaan moral dan akhlak, Pemberian ancaman. dan yang kedua adalah upaya represif meliputi : Penegakan terhadap aturan yang ada, skorsing atau pemecatan terhadap pelaku, dan menindak para pelaku dengan peroporsional dan provisional, Melapor Polisi.

Berdasarkan hasil pemaparan dari penelitian ini, dan ditemukan permasalahan, maka peneliti akan memberikan beberapa implikasi penelitian sebagai berikut:

a. Berkenaan dengan keberadaan tindak pidana yang terjadi dalam kampus, olehnya itu perlu ada perhatian khusus dari pihak kampus untuk lebih selektif dan lebih memperhatiakn terhadap imput dan proses kebijakan yang dilakukan dalam pelaksanaan pendidikan dalam kampus.

b. Kepada seluruh pihak yang terkait turut andil dalam mencegah terjadinya tindak pidana dalam kampus khusunya keterlibatan dari pihak masyarakat, keluarga para mahasiswa dan penegak hukum dan penegakan aturan yang telah ada.

\section{Daftar Pustaka}

Anwar Yesmil, (2009). Saat Menuai Kejahatan Sebuah Pendekatan Sosiokultural, kriminologi, Hukum, dan HAM., Bandung, PT. Refika Aditama.

Aminuddin, (2004). Pengantar Penelitian Hukum, Jakarta, Raja Grafindo.

Arief, Barda Nawawi, (2001) Masalah Penegakan Hukum dan Kebijakan Penanggulangan Kejahatan, Bandung, PT. Citra Aditya Bakti.

Arief, Barda Nawawi, (2008) Masalah penegakan hukum dan kebijakan hukum pidana dalam penanggulangan kejahatan, Jakarta, Prenada Media Group.

Arief, Barda Nawawi, (2011) Bunga Rampai Hukum Pidana, Semarang, Fajar Interpratama.

Arief, Barda Nawawi, (2008) Bunga Rampai Kebijakan Hukum Pidana (Perkembangan Penyusunan Konsep KUHP Baru), Jakarta, Kencana Prenada Media Group.

Arrasjid, Chainur, (1998) Suatu Pemikiran Tentang Psikologi Kriminil, Medan, Yani Corporation.

Atmasasmita, Romli, (1992) Teori dan Kapita Selekta Kriminologi, Bandung, Penerbit PT. Eresco.

Bawengan, G.W., (1991) Pengantar Psikologi Kriminal, Jakarta, Pradya Paramitha.

Bonger, W.A., (1982) Pengantar Tentang Kriminologi, Jakarta, PT. Pembangunan Ghalia Indonesia.

Darma Weda, Made, (1996) Kriminologi, Jakarta, PT. Raja Grafindo Persada.

D., Soedjono, Konsepsi Kriminologi Dalam Usaha Penanggulangan Kejahatan,

Muhammad, Abdulkadir, (2004) Hukum dan Penelitian Hukum, Bandung, Citra Aditya Bakti.

Santoso, Topo dan Achjani Zulfa, Eva (2005) Kriminologi, Jakarta, PT. Raja Grafindo Persada.

Widiyanti, Ninik dan Anoraga, Panji. (1987), Perkembangan Kejahatan dan Masalahnya, Jakarta, Pradya Paramita. 